\title{
Foreign Direct Investment in the Eastern European Countries: \\ Determinants and Performance
}

\section{Introduction}

A substantial empirical literature is dedicated to examining the determining factors of foreign direct investment (FDI) to the eastern European countries for several reasons. First, an unprecedented number of investors - especially from the western European countries - have located their activities in these countries since the mid 1990s. A plot of outward FDI stocks to the 10 new member countries of the European Union (EU) summed across 10 western European countries over the 1996 to 2007 period is shown in Figure 1. Poland leads the field of 10 eastern European countries with FDI volumes surging from US\$7 billion to nearly US\$90 billion, implying a double digit annual growth rate of 11 per cent over the period. Together with the Czech Republic and Hungary, the big trio dominate FDI volumes into the region, although their joint share of this volume has declined from 90 to 75 per cent. Romania and Slovakia have made substantial inroads into the region's share of FDI; their joint share accounted for nearly one fifth of FDI to all 10 new member states by 2007. In comparison, FDI stocks to the other five countries (Bulgaria, Estonia, Latvia, Lithuania and Slovenia) have remained subdued in volume. Most impressive, nevertheless, is Estonia's growth rate of FDI in excess of 200 times its initial 1996 volumes, albeit from a low base.

[Insert Figure 1 here]

Second, FDI is an important source of external finance in the formation of capital and facilitates the transfer of resources, human capital and technological progress between countries, thereby representing an important means by which the transition economies can promote growth 
and development. Last, the changing nature of FDI is an important means of studying the process of liberalisation towards market based regimes.

Previous empirical studies on the transition economies tend to link FDI determinants to the traditional market seeking and efficiency seeking motives of overseas investment, but these studies are not grounded in the theoretical underpinnings based on formal theories of the multinational enterprise (MNE). More recently, the observation that much of global trade is conducted by MNEs has prompted microeconomic general equilibrium extensions of the trade literature in which MNEs also feature.

Six types of firms can exist in equilibrium: two national firms, two vertically integrated MNEs and two horizontally integrated MNEs; two of each firm type because a firm can be located either in the home or the foreign country. Built on the new trade theory, national firms exist only if international factor prices are equalised and the volume of trade increases with similarities in relative country size (Helpman 1987; Helpman and Krugman 1985). If international factor prices are unequal, vertically integrated MNEs that geographically separate headquarter (HQ) activities from production activities are formed in response to dissimilar factor endowments (Helpman 1984; Helpman and Krugman 1985). In another strand of the literature, a horizontally integrated MNE seeking to increase foreign market share and economise on trade costs can arise in equilibrium. While Markusen (1984) emphasises firm specific assets that are characterised with a 'public good' or 'jointness' aspect of the firm's production activities which eliminates the need to duplicate the joint inputs across plants, Brainard (1993) formulates the choice between exporting and MNE production in terms of a trade off between proximity to customers and concentration of production. 
Theoretical developments brought about an empirical specification. Known as the knowledge capital (KK) model, Markusen and Maskus (2001) and Carr et al. (2001) estimate a hybrid model which combines the motives of vertically and horizontally integrated firms based on the simulated predictions of Markusen et al. (1996) and Markusen (1997). Different country characteristics favour different firm types. Specifically, national firms dominate other firm types under three scenarios: first, the country is large and is skilled labour abundant; second, trade costs are low and countries are similar in size and in relative endowments; and third, investment barriers in the foreign country are high. As countries become increasingly different in relative factor endowments, factor price equalisation fails to hold and vertically integrated firms enter the market, locating their production facilities in the unskilled labour abundant country. Therefore, vertical MNEs dominate when trade costs remain low and countries differ substantially in relative factor endowments, although they may be somewhat similar in size. Horizontal MNEs, on the other hand, dominate production when trade costs are moderate to high and countries are similar in size and in relative factor endowments.

The contributions of this paper are three fold. First, in relating FDI to country characteristics, the KK model is estimated for a panel of bilateral FDI stocks from 10 western European countries to 10 eastern European countries over the 1996 to 2007 period. As the data do not distinguish between the differing types of FDI, estimating the hybrid model provides an insight into the dominant motive for investing in the eastern European economies over the transition phase from communism to EU accession. While previous findings on the market seeking motive are uncontroversial, ${ }^{1}$ the results relating to the efficiency seeking motive are

\footnotetext{
${ }^{1}$ Most studies have confirmed the importance of the market-seeking motive for the transition economies, whether proxied by GDP (Bevan and Estrin 2004), population (Egger and Pfaffermayr 2004) or market potential, as
} 
mixed. For example, Carstensen and Toubal (2004) obtain a negative and significant coefficient for relative unit labour costs, Clausing and Dorobantu (2005) find the coefficient for average compensation rates to be marginally significant only while the findings of Demekas et al. (2007) suggest the negative effect of unit labour costs disappears above a specified threshold. Furthermore, Bellak et al. (2008) note that labour costs are of minor importance compared with the core gravity variables.

Increasingly important in attracting FDI to the eastern European countries is the quality of labour rather than the cost of labour. These countries possess a highly educated labour force, ${ }^{2}$ allowing them to benefit from the technology and knowledge transfer associated with FDI. Indeed, their country characteristics - a tendency towards the top right hand corner of the 'Edgeworth box' of world endowments (the upper position because of their relatively small size, the right hand side position because of their relatively skilled labour force) - are closely related to the theoretical KK model framework. Also focusing on the corner case of the Edgeworth box, Kristjánsdóttir (2010) use the KK model in an analysis of Icelandic inward FDI.

The KK model also takes account of the institutional environment, which can affect FDI in different ways. While high trade barriers tend to induce horizontal FDI (HFDI) while reducing vertical FDI (VFDI), high barriers to investment tend to deter both types. Not previously emphasised in the traditional literature, the effects of barriers to both trade and FDI in the eastern European countries are estimated.

measured by the market size of neighbouring countries (Carstensen and Toubal 2004). Indeed, the core gravity variables (market size and proximity) are consistently found to be the most important explanatory variables of FDI.

${ }^{2}$ Comparing the percentage ratio of enrolment in tertiary education (World Development Indicators, World Bank), the average value for the ten eastern European countries in the analysis (61.6) is similar to that of the ten western European countries (67.6), although there is some degree of variability between the countries. 
Second, the changing nature of FDI is assessed over time. Specifically, the relative importance of HFDI and VFDI is evaluated before and after EU entry. The consequences of economic integration can have ambiguous effects on FDI: on the one hand, access to larger markets promotes HFDI while, on the other hand, lower trade barriers reduce the incentives for HFDI and at the same time induce VFDI.

Third, observed FDI is assessed against a maximum level of FDI feasible for the group of 10 eastern European countries using efficiency scores generated from a stochastic frontier approach to estimating the KK model. If two countries achieve an efficient level of FDI, they will operate on the frontier and will realise their maximum FDI potential otherwise deviations of observed FDI levels from frontier estimates indicate inefficient levels of FDI, implying scope for improved FDI performance. Similar in approach to that used by Armstrong (2011) who examines the performance of China's investment overseas, the frontier specification of the KK model represents a new approach to assessing FDI potential over existing measures which benchmark FDI potential (using a set of economic and policy factors) against FDI performance based on a standardised measure of a country's inward FDI to the size of its economy (Rodríguez et al. 2009f; Rojec and Damijan 2008; UNCTAD 2002) or the deviation from predicted levels given optimal policies (Demekas et al. 2007).

The layout of this paper is as follows. Based on the unified treatment of horizontally and vertically integrated MNEs, Section 2 presents the KK model specification relating FDI to country characteristics. The model definitions and data sources are set out in Section 3. The results in Section 4 are split between the KK model coefficient estimates and the efficiency scores of FDI performance. Section 5 concludes. 


\section{Model specification and estimation strategy}

\subsection{The knowledge capital model}

Following the general equilibrium extensions of the trade literature which give rise to MNEs, the specification for the knowledge capital (KK) model of affiliate sales estimated by Carr et al. (2001) and applied to FDI stocks (Blonigen et al. 2003) ${ }^{3}$ is:

$$
\begin{aligned}
& F D I_{i j}^{t}=\beta_{0}+\beta_{1} G D P_{i}^{t}+\beta_{2} G D P_{j}^{t}+\beta_{3} D G D P S Q_{i j}^{t}+\beta_{4} D I S T_{i j} \\
& +\beta_{5} \text {TRADECOST }_{i}^{t}+\beta_{6} \text { TRADECOST }_{j}^{t}+\beta_{7} \text { INVCOST }_{j}^{t} \\
& +\beta_{8} D S K I L L_{i j}^{t}+\beta_{9}\left(D G D P_{i j}^{t} \times D S K I L L_{i j}^{t}\right) \\
& +\beta_{10}\left(T R A D E C O S T_{j}^{t} \times D S K I L L S Q_{i j}^{t}\right)+\varepsilon_{i j}^{t}
\end{aligned}
$$

where $F D I_{i j}^{t}$ are the outward bilateral FDI stocks, in US dollars at constant 2000 prices, from 10 western European countries (countries $i$ ) into 10 new EU member countries (countries $j$ ) over the (time $t$ ) period 1996 to 2007; GDP $P_{i}^{t}$ and $G D P_{j}^{t}$, in constant 2000 US dollars, denote the economic size for both countries; the difference of GDP squared, $D G D P S Q_{i j}^{t}=\left(\ln G D P_{i}^{t}-\ln G D P_{j}^{t}\right)^{2}$, represents the similarity of country size; and distance, $D I S T_{i j}$, is a geographic measure of transport costs between their economic centres. ${ }^{4}$

Three measures of the perceived costs associated with trading and investing abroad capture the institutional environment in the eastern European countries: an index measure of

\footnotetext{
${ }^{3}$ Qualitatively similar results are obtained when FDI stocks are used instead of affiliate sales data, not surprising as FDI stocks is a reasonable proxy for output, as represented by the gross product of majority owned affiliates (Lipsey 2000).

${ }^{4}$ Equation (1) differs from the KK model only in form: whereas GDP for both countries enters equation (1) separately, GDP enters the KK model jointly as the sum of both countries' market size.
} 
trade protectionism for both countries, TRADECOST ${ }_{i}^{t}$ and $T R A D E C O S T_{j}^{t}$, and an index measure of investment restrictions for the host country, INVCOST ${ }_{j}^{t}$, where restrictions are implied to involve more costs.

The difference in skilled labour between the two countries, $D S K I L L_{i j}^{t}=\left(\ln S K I L L_{i}^{t}-\ln S K I L L_{j}^{t}\right)$, is a proxy for relative factor endowments. Two interaction terms capture the interplay of relationships. The first interaction term, $\left(D G D P_{i j}^{t} \times D S K I L L_{i j}^{t}\right)$, is the product of the differences in economic size, $D G D P_{i j}^{t}=\left(\ln G D P_{i}^{t}-\ln G D P_{j}^{t}\right)$, and skilled labour endowments. The second interaction term, $\left(T R A D E C O S T_{j}^{t} \times D S K I L L S Q_{i j}^{t}\right)$, is the product of trade costs in the host country and the difference between skilled labour endowments squared, where $D S K I L L S Q_{i j}^{t}=\left(\ln S K I L L_{i}^{t}-\ln S K I L L_{j}^{t}\right)^{2}$. The error term is denoted as $\varepsilon_{i j}^{t}$. All variables in equation (1) are estimated in natural logarithms (ln) except for the index measures of trade costs and investment costs.

As with the new trade theory which posits that larger countries and similarly sized countries tend to trade more, these country characteristics lead to more HFDI in the KK model. The GDP coefficients and the difference of GDP squared, DGDPS $Q_{i j}^{t}$, should therefore be positively and negatively signed respectively. The geographic distance, $D I S T_{i j}$, represents an element of trade and investment costs. As an element of trade costs, its coefficient sign is ambiguous, depending on the prevailing type of FDI. Whereas a positive and significant effect points to HFDI aligned with the tariff jumping motive, a negative and significant effect suggests trade costs have a deterring effect on VFDI. As an element of investment costs, restrictions on 
FDI discourage all foreign investors, implying an expected negative coefficient regardless of the FDI type.

An index of trade protectionism for both countries is included as a measure of trade costs. Its coefficient is expected to be positive in sign for the host country, $T R A D E C O S T_{j}^{t}$, because high trade costs stimulate HFDI in the destination market, but a negative sign is expected for the home country, TRADECOST ${ }_{i}^{t}$, because high trade costs reduce the VFDI incentive to locate plants abroad for the shipment of goods back to the home market. As a measure of trade costs, the cost indexes capture trade restrictions with all trading partner countries in the spirit of multilateral trade resistances identified by Anderson and van Wincoop (2003). The index of investment restrictions, INVCOST $T_{j}^{t}$, reflects an array of investment barriers which impede FDI. In principle, skilled labour differences, $D S K I L L_{i j}^{t}$, can be ambiguously signed, but as a firm tends to be headquartered in the skilled labour abundant country its sign is predicted to be positive. A negative coefficient sign is expected for the first interaction term, $\left(D G D P_{i j}^{t} \times D S K I L L_{i j}^{t}\right)$, in favour of VFDI and the geographic separation of a firm's headquarters from its production facilities. According to the simulations of Carr et al. (2001), affiliate production is highest when the home country is relatively small and is highly skilled labour abundant. Therefore, the firm's headquarters will be located in the home country, which is abundant in skilled labour and the firm's production facilities will be located in the foreign country, which is large enough to support production at a lower cost. The coefficient for the second interaction term, (TRADECOST $\left.{ }_{j}^{t} \times D S K I L L S Q_{i j}^{t}\right)$, is expected to be negative in sign because VFDI weakens the positive association between HFDI and high trade costs, although an ambiguous effect is possible because it is not a theoretically sharp hypothesis. 


\subsection{The knowledge capital model estimated using stochastic frontier analysis}

To assess FDI performance between the western and the eastern European countries, the KK model is estimated using stochastic frontier analysis (SFA). Estimating the KK model as a stochastic frontier specification involves sub dividing the right hand side variables into two subsets: the core gravity variables and policy related factors. The first subset of GDP and skills related variables are used to identify the maximum possible level of FDI on the frontier, thereby forming an upper boundary of FDI levels against which observed FDI levels can be benchmarked. The second subset of policy oriented cost variables are used to capture the distance between observed levels of FDI and frontier estimates. While policymakers have a limited role in influencing the first subset of variables, (national income and the quality of labour cannot easily be altered in the short run), the gap between actual and maximum FDI levels can be closed by improving the institutional environment and creating a healthy investment climate.

Performance analysis within the SFA framework proceeds by determining a frontier function against which actual performance is benchmarked. In a production context, SFA can be used to determine the maximum output that can be produced given the input bundle used and existing technology. Actual observed output of fully efficient firms coincides with frontier levels of output if production is technically efficient, but will deviate from the frontier if production is technically inefficient. In other words, a firm operating at a point within the frontier indicates a shortfall between the observed and the maximum possible level of output, implying scope for improved firm performance. Used extensively in the analysis of firm performance, SFA in the current context is used to examine foreign investor performance. Specifically, bilateral FDI performance is defined relative to a maximum possible level of FDI for a given country pair. 
Proposed by Aigner et al. (1977) and Meeusen and van den Broeck (1977), SFA provides an avenue to estimating frontier functions and efficiency estimates. Specifically, the error term is constructed as the sum of the symmetrically distributed random error term and a non negative, technical inefficiency term. Given the distributional assumption for the composed error term, parameter values for the frontier are obtained through maximum likelihood (ML) estimation.

Adapting the KK specification to the SFA framework thus involves two fundamental changes to equation (1). First, the error term is decomposed into two parts namely a random error term and an inefficiency term. Second, the explanatory variables are subdivided into two groups representing the frontier and the distance from the frontier. The stochastic frontier specification of the KK model is specified as follows:

$$
\begin{aligned}
F D I_{i j}^{t}= & \theta_{0}+\theta_{1} G D P_{i}^{t}+\theta_{2} G D P_{j}^{t}+\theta_{3} D G D P S Q_{i j}^{t}+\theta_{4} D I S T_{i j} \\
& +\theta_{5} D S K I L L_{i j}^{t}+\theta_{6}\left(D G D P_{i j}^{t} \times D S K I L L_{i j}^{t}\right) \\
& +\theta_{7}\left(T R A D E C O S T_{j}^{t} \times D S K I L L S Q_{i j}^{t}\right)+v_{i j}^{t}-u_{i j}^{t}
\end{aligned}
$$

where the error term, $\varepsilon_{i j}^{t}$, in the conventional KK specification (equation 1) is now comprised of two parts, the first of which is a symmetric error element, $v_{i j}^{t} \sim i i d N\left(0, \sigma_{v}^{2}\right)$, which is the usual random error term representing statistical noise and measurement error. Unique to SFA, the second component is a one sided inefficiency element, $u_{i j}^{t}$, assumed to be distributed independently of the random error and the regressors. Its magnitude indicates whether observed FDI levels will be located on or below the FDI stochastic frontier, $f(K K ; \theta)+v_{i j}^{t}$, which will vary for each country pair due to the symmetric random error component (Aigner et al. 1977). ${ }^{5}$

\footnotetext{
${ }^{5}$ The random error captures random variation of the frontier across the bilateral country pairs (Fried et al. 2008) whereas the inefficiency component solely represents deviations from the FDI frontier.
} 
A measure of FDI performance specific to each country pair can thus be obtained as $F D I / f(K K ; \theta)+v_{i j}^{t}$, which takes a value between zero and unity. Whereas an efficiency score of unity suggests actual and maximum FDI levels coincide on the frontier, values closer to zero indicate scope to raise actual FDI levels closer to frontier estimates.

Following Battese and Coelli (1995), the inefficiency component is obtained as non negative truncations of a normal distribution with mean, $\delta_{m} z_{m, i j}^{t}$, and variance, $\sigma_{u}^{2}$. In the context of the KK model, the mean of inefficiency is specified as follows:

$$
u_{i j}^{t}=\delta_{0}+\delta_{1} T R A D E C O S T_{i}^{t}+\delta_{2} T_{R A D E C O S T}^{t}+\delta_{3} I N V C O S T_{j}^{t}
$$

where the cost variables are the inefficiency determinants representing the distance from frontier estimates. The one sided inefficiency component thus captures the institutional determinants of FDI along with other unobservables that give rise to deviations from frontier estimates. ${ }^{6}$ Finally, the values for technical efficiency (TE) for each country pair are obtained as the conditional expectation of $\exp \left(-u_{i j}^{t}\right)$ given $\varepsilon_{i j}^{t}$ (Battese and Coelli 1993):

$$
T E_{i j}^{t}=E\left[\exp \left(-u_{i j}^{t}\right) \mid \varepsilon_{i j}^{t}\right]=\left[\exp \left(-\mu_{i j}^{t}+\frac{1}{2} \sigma_{*}^{2}\right)\right] \cdot\left[\Phi\left(\frac{\mu_{i j}^{t} / \sigma_{*}-\sigma_{*}}{\mu_{i j}^{t} / \sigma_{*}}\right)\right]
$$

where

$$
\begin{aligned}
& \mu_{i j}^{t}=(1-\gamma)\left[\delta_{0}+\sum_{m=1}^{M} \delta_{m} z_{m, i j}^{t}\right]-\gamma \varepsilon_{i j}^{t} \\
& \sigma_{*}^{2}=\gamma(1-\gamma) \sigma^{2}
\end{aligned}
$$

and $\Phi($.$) is the distribution function of the standard normal random variable.$

\footnotetext{
${ }^{6}$ Unobservable transition-related factors include the development of financial institutions, the building of transport facilities and the required amount of time it takes for businesses to establish new contacts.
} 


\section{Data}

The panel data set consists of bilateral FDI stocks from 10 western European countries comprising eight established EU countries and two EFTA member countries ${ }^{7}$ to 10 new member states $^{8}$ over the period 1996 to 2007. Since the fall of communism, these countries have received unprecedented volumes of FDI, most of which originates from their western counterparts. The sample period covers the transition phase from communism to EU accession, ending in 2007 before the distortionary effects of the global financial crisis interrupt normal FDI patterns.

The data sources are as follows. FDI stocks, in US dollars, are obtained from the International Direct Investment Statistics (IDIS), Organisation for Economic Cooperation and Development (OECD). Expressed in real terms, FDI stocks are deflated by US producer prices $(2000=100)$, sourced from the International Financial Statistics (IFS), International Monetary Fund (IMF). GDP, at constant 2000 US dollars, is from the World Development Indicators (WDI), World Bank. The geographic distance between two economic centres, measured in kilometres, is from the CEPII.

The economic freedom indexes are from The Heritage Foundation. The trade freedom index is a composite measure of the absence of tariffs and non tariff barriers (NTBs); while higher tariffs directly raise the cost of trade, NTBs indirectly raise the cost of trade by limiting access to markets through a variety of restrictions on the quantity, price and regulation of traded goods. The investment index is a composite measure of the freedom investors have in a market which is curtailed by different rules for foreign and domestic investment; sectoral investment restrictions; the expropriation of investments without fair compensation; foreign exchange

\footnotetext{
${ }^{7}$ Austria, Denmark, Finland, France, Germany, Italy, the Netherlands, Norway, Switzerland, the United Kingdom.

${ }^{8}$ Bulgaria, the Czech Republic, Estonia, Hungary, Latvia, Lithuania, Poland, Romania, Slovakia, Slovenia.
} 
controls; controls on capital movements and profit repatriation and bureaucracy that burdens the investment process. Defined in terms of the absence of trade and investment restrictions, a measure of the presence of restrictions is obtained by subtracting the economic freedom index values from 100 so that higher values represent higher barriers.

Skilled labour, from the WDI is represented by the percentage ratio of enrolment in tertiary education. Enrolment information is in general available since 1999 and is not available for Germany. To prevent loss of information, pre 1999 data for each country consists of period averages $;^{9}$ for Germany, secondary school enrolment ratios are used. The summary statistics for the model variables are shown in Table 1. The correlation matrix for the independent variables is shown in Table 2.

[Insert Tables 1 and 2 here]

\section{Empirical results}

\subsection{The knowledge capital model estimates}

Table 3 presents the maximum likelihood (ML) estimates for the stochastic frontier specification of the KK model of FDI stocks from 10 western European countries to 10 new member states over the 1996 to 2007 period. Column (1) shows the results for the KK model over the full sample period. To gain an insight into the changing nature of FDI over time, columns (2) and (3) show the subsample results for the pre EU accession years (1996 to 2003 and 1996 to 2006) and the post EU accession years (2004 to 2007 and 2007) for eight eastern European countries and the two newer member countries respectively.

[Insert Table 3 here]

\footnotetext{
${ }^{9}$ Carr et al. (2001) also use period averages for missing skilled-labour ratios.
} 
The $\gamma$ parameter - the ratio of the variance of the inefficiency component, $\left(\sigma_{u}^{2}\right)$ to the variance of the composed error term $\left(\sigma^{2}\right)$ - is significant except for the post EU subsample. Ranging in value from 0.68 to 0.83 , a high proportion of the variation in the composed error term is attributed to the inefficiency component rather than the random error component in support of the frontier specification of the KK model.

Taking in turn each of the KK model coefficients, the GDP elasticity coefficients are positive and significant, indicating market size matters for FDI. Specifically, on the supply side large countries invest more abroad; on the demand side the eastern European countries' more outward orientation and concomitant access to large markets attracts HFDI. Their summed values suggest FDI is elastic with respect to total GDP in line with the KK model prediction that the joint market size coefficient should be greater than unity because an increase in income raises affiliate production by a greater proportion. A comparison of the GDP coefficient magnitudes for the pre EU and the post EU subsamples underlines the increasing importance of access to new markets over time. A convergence of size similarity between the western and the eastern European countries also increases FDI, as suggested by the negative and significant coefficient for the squared difference of GDP. Although the GDP related country characteristics favour HFDI, their significance do not necessarily indicate the absence of VFDI, which can exist under these conditions when trade costs are low.

Greater distance constrains FDI. Interpreting a negatively signed coefficient for distance as evidence in support of VFDI among the industrialised countries, Mariel et al. (2009) note that high transaction costs associated with distance can also hamper HFDI. Nevertheless, its smaller coefficient for the post EU subsample suggests regional integration mitigates the deterring effect of transaction costs on VFDI. 
In contrast to the KK model's predicted positive effect for the skilled labour difference, its coefficient is consistently negative and significant, indicating the presence of similar rather than different labour endowments in favour of HFDI. Requiring technical skills to build knowledge based industries, the Czechs and the Hungarians have been particularly successful in attracting high quality foreign investment. The effect becomes even more negative across the subsamples as the eastern European countries enhance and upgrade their education and skills base.

The coefficient for the first interaction term, the product of the differences in the economic size and skilled labour endowments, is positive at odds with the view that FDI abroad is highest when the home country is small and is relatively skilled labour abundant. Carr et al. (2001) had suggested the Netherlands, Sweden and Switzerland fit this category of countries. The positively signed coefficient, however, suggests VFDI gives way to national firms which benefit from economies of scale in the home country and serve foreign markets by exports. As incomes converge and countries become increasingly similar in size, HFDI will eventually replace these national firms. In lieu of the second interaction term between the host country trade cost index and the square of skilled labour differences the negatively signed coefficient suggests high trade costs coupled with similar skilled labour endowments reduces VFDI.

The ML results for the trade cost indexes suggest a mixed pattern of HFDI and VFDI. Note the different interpretation for the cost coefficients here. The KK model predicts the composite measures of trade restrictions will either stimulate HFDI or impede VFDI. Cast as inefficiency determinants using the SFA approach (Battese and Coelli 1995), opposing coefficient signs are expected. In particular, the negatively signed coefficient for trade costs in the host country is consistent with greater efficiency of HFDI whereas the positively signed 
coefficient for trade costs in the home country suggests a reduced efficiency of VFDI. In other words, trade costs motivate outward HFDI from the western European countries while, in the opposite direction, the VFDI motive is restricted by trade costs in the home country. On the whole, the relatively low magnitudes and broadly insignificant coefficients suggest a low degree of multilateral resistances. In other words, eligibility for EU accession has brought about the removal of trade barriers and introduced reforms under the Acquis Communautaire.

Remaining barriers to investment decrease FDI. In accordance with the predictions of the KK model and the SFA interpretation of a reduced efficiency of FDI, the positive coefficient for the investment cost index indicates both types of FDI are discouraged. While Smarzynska Javorcik (2004) note that the magnitude of the effect tends to be higher for developing countries that lag behind in technological sophistication, Yeaple (2003) suggests the effect of FDI barriers is greater for vertical FDI. Although relatively low in magnitude, the effect becomes significant post EU accession, implying scope to further liberalise investment and improve the quality of the institutional environment.

\subsection{Robustness checks}

Overall, the KK model parameters suggest a dual role for HFDI and VFDI patterns between the western and the eastern European countries over the period 1996 to 2007. Several checks on the results are undertaken to confirm the robustness of the KK model proxy variables. First, as the two interaction terms are highly correlated with the skills difference variable (see Table 2), the KK model is reestimated without these terms. Column (1) of Table 4 suggests the results are robust to the exclusion of the interaction terms; although the coefficient magnitude for the skills difference variable is reduced, its sign and significance remains intact. 
Second, the restriction indexes are redefined in terms of trade and investment intensities. This convention follows Blonigen et al. (2003) who express the trade cost variable as 100 less the value for trade openness, defined as the trade to GDP ratio, TRADECOST $=\left\{100-\left[\left(X^{t}+M^{t}\right) / G D P^{t}\right]\right\}$, where $X^{t}, M^{t}$ and $G D P^{t}$ are total country exports, imports and GDP respectively. Similarly defined, the investment cost variable can be expressed as 100 less the value for FDI openness, INVCOST $=\left\{100-\left[\left(O U T^{t}+I N^{t}\right) / G D P^{t}\right]\right\}$, where $O U T^{t}$ and $I N^{t}$ are total country outward and inward FDI stocks respectively. The trade to GDP ratio is sourced directly from the World Development Indicators (WDI) and the FDI to GDP data are obtained from UNCTAD and the WDI respectively. Shown in column (2), the results indicate all three cost indexes are significant with coefficient signs as expected. The magnitude for the investment cost index, however, seems unrealistically high and therefore may not be the best measure of FDI restrictions. Moreover, the insignificance of the $\gamma$ parameter indicates that the variation in the composed error term is due to the random error term.

[Insert Table 4 here]

Third, focusing mainly on the skills difference variable, several amendments to the model have been proposed in response to criticism that the KK model does not adequately account for VFDI. Blonigen et al. (2003) argue that when skilled labour differences are specified in absolute terms, the horizontal model cannot be rejected in favour of the KK model. As shown in column (3), substituting the difference of skilled labour for its difference in absolute values does not materially affect the KK model results apart from some minor changes to the coefficient magnitudes and an insignificant second interaction term. ${ }^{10}$ To allow for a nonmonotonic

\footnotetext{
${ }^{10}$ Splitting the data into two subsets representing relatively skilled labour home countries and relatively skilled labour host countries is also useful in teasing out the VFDI motive (Markusen and Maskus 2002; Blonigen et al.
} 
relationship between FDI and skills differences, Davies (2008) appends the square of the skills difference to the KK model specification. The results in column (4) suggest both the skills difference and its squared term negatively affect FDI, implying a linear and nonlinear effect.

Given the data limitations on tertiary enrolment rates, the KK model is reestimated using the difference between secondary school enrolment rates, SKILLS2, available from the World Development Indicators, and its associated interactions (Kristjánsdóttir 2010). The results shown in column (5) indicate no substantial changes to the model coefficients apart from the nonsignificance of the skills difference variable; any differences arising from secondary school enrolment rates do not significantly affect FDI. As an additional robustness check on the skills difference variable, the model is reestimated for the period 1999 to 2007 corresponding to when a full set of information is available for enrolment rates with no discernible changes shown in column (6) except that all three cost variables are now insignificant at conventional levels.

The remaining set of results in Table 4 check the robustness of the maximum likelihood estimations against alternative estimators. The results shown in column (7) include country dummies to allow for heterogeneity among the group of 10 eastern European countries while in column (8) the standard errors in column (7) are adjusted for heteroscedasticity. All cost indexes become insignificant and the magnitude for the host country GDP increases, otherwise the remaining KK model results remain intact.

Finally, the results may suffer from endogeneity bias arising from the simultaneous determination of FDI and some of the explanatory variables. ${ }^{11}$ For example, more FDI inflows

2003). Generating efficiency scores from two separate frontiers, however, will reduce comparability of the results and so is avoided here.

${ }^{11}$ We thank an anonymous referee for suggesting the possibility of endogeneity arising from dual causality. 
can potentially lead to higher GDP. The volume of inward FDI can also induce governments to reduce restrictions on investment. To alleviate the potential problem of simultaneity bias, the KK model is reestimated using the two stage least squares (2SLS) approach. A one period lagged value is used as an instrument for the GDP related variables and the investment cost index. All other variables serve as their own instruments. Although the core KK model variable coefficients remain broadly unchanged, the 2 SLS results indicate trade and investment costs significantly affect FDI.

\subsection{Additional inefficiency determinants}

Restrictions on trade and investment are not the only policy factors that can affect FDI; foreign investment in the eastern European countries is potentially influenced by other factors that are not explicitly addressed in the KK model. For example, low labour costs have long been associated with the VFDI motive of cost efficiencies. Foreign investment can also be induced by economic and political stability. The findings of Globerman and Shapiro (2002), for example, suggest a country's governance infrastructure - defined in terms of its political, institutional and legal environment - is a plausible determinant of FDI for a broad sample of both developed and developing country locations.

The flat tax system, characteristic of many eastern European countries, can also incentivise foreign investment on the grounds of simplicity and transparency and because the relatively lower corporation tax rates increases firm profitability. ${ }^{12}$ Finally, a good domestic

\footnotetext{
${ }^{12}$ Flat taxes, whereby a constant marginal rate is applied to income tax - personal, corporate or both - have flourished throughout ex-communist Europe since Estonia's adoption of a flat taxation system in 1994. Latvia and Lithuania soon followed suit in 1995; while Slovakia and Romania joined the club of flat taxes in 2004 and 2005 respectively. More recently, flat taxes have also spread to the Czech Republic and Bulgaria in 2008. Beyond the
} 
capital base can attract more capital from abroad while a good infrastructure network is especially appealing to foreign investment of the vertical type. As with the trade and investment cost indexes, opposing coefficient signs are expected for the policy determinants of FDI inefficiency within the SFA framework because less inefficiency helps close the gap between actual and potential FDI performance.

Extending the KK model to allow for policy determinants of FDI inefficiency, the results are shown in Table 5. In column (1), the cost of labour, measured as the real manufacturing wage index, sourced from the Key Indicators of the Labour Market (KILM), International Labour Organisation (ILO), is shown to negatively affect FDI inefficiency, contrary to an expected positive coefficient sign. In line with the mixed evidence in the literature this empirical ambiguity can arise from the use of data unadjusted for productivity, but can still be consistent with the predictions of the labour cost hypothesis. Indeed, Resmini (2000) argues that the high quality of labour in the eastern European countries means that the gap in productivity with the western European countries is less important than the wage cost differential.

[Insert Table 5 here]

In columns (2) and (3), neither economic nor political instability pose a problem for foreign investment in the eastern European countries, as indicated by the insignificant coefficients for the international perception measures, obtained from the International and Country Risk Guide (ICRG). ${ }^{13}$ Low taxation, defined as the highest marginal tax rate on the

\footnotetext{
sample period, Hungary adopted the system of flat taxes in 2011. The single income tax rate, however, has since been replaced with a progressive scheme in the Czech Republic and Slovakia.

${ }^{13}$ The economic risk rating is a composite index comprising five indicators of economic risk, namely income per head, real GDP growth, the annual inflation rate, the budget balance and the current account - the latter two as a share of GDP. The political risk rating comprises 12 indicators of political risk: government stability, socioeconomic
} 
schedule of tax rates applied to the taxable income of corporations, taken from the WDI, World Bank, matters for FDI, as shown in Column (4). The coefficient for domestic capital stocks, measured by gross capital formation as a share of GDP from the WDI, World Bank, is correctly signed and significant in column (5).

Finally and most important in reducing the inefficiency of FDI is the state of the physical infrastructure in the eastern European countries, as shown in column (6). Relating to the reform of telecommunications, railways, electric power, roads as well as water and waste water, available from the European Bank for Reconstruction and Development (EBRD), the coefficient for the overall index is significant and its magnitude is substantial. Clearly, the development of a modern and efficient infrastructure is an essential policy instrument towards achieving potential FDI. In addition to corporate income taxes, Bellak et al. (2008) have previously highlighted the importance of infrastructure endowments as determinants of FDI in the eastern European countries.

Putting all the policy variables together, the results for the full model are shown in column (7). While the coefficients for the structural variables of the KK model remain unchanged, the trade and investment cost indexes are superseded in significance by the policies relating to labour costs, taxation and infrastructure. Note that the independent effect of domestic capital stocks becomes insignificant in the full model as its effect is picked up by the state of physical infrastructure. Replacing the policy variables with time effects (column 8) or host country fixed effects (column 9) has no material consequences on the model coefficients.

conditions, the investment profile, internal and external conflict, corruption, the involvement of the military in politics, religious tensions, law and order, ethnic tensions, democratic accountability and bureaucracy. 


\subsection{Direct investment efficiency scores}

Satisfied that both HFDI and VFDI are represented in the KK model, the focus of attention now turns to examining the efficiency of FDI performance between the two sets of countries. The FDI efficiency scores for each bilateral pair of countries associated with the stochastic frontier specification of the KK model (column 1 of Table 3) and averaged over the years 1996 to 2007 are shown in Table $6 .{ }^{14}$ High efficiency scores suggest direct investment between two countries is close to their maximum levels whereas low efficiency scores indicate deviations of actual FDI from frontier estimates, implying scope for improved FDI performance.

[Insert Table 6 here]

Considerable variability characterise the efficiency scores, indicating a very uneven performance of FDI among the new member states. A high degree of regional specialisation is in evidence between the Baltics and Denmark and between the Czech Republic and the Netherlands. Particularly high scores are also found for Hungary vis à vis Finland, Germany and the Netherlands.

Averaging the efficiency scores across the ten western countries, Estonia and Hungary fare best, achieving over half their maximum potential values. Take, for example, Estonia. After the collapse of the Soviet Union in 1991, an extensive privatisation programme coupled with the lifting of foreign ownership restrictions lured in hefty foreign investment, spurring a boom in its manufacturing and service industries. Other industries previously closed to foreign investors, including the telecommunications sector, were also liberalised. Skype, an internet telephony

\footnotetext{
${ }^{14}$ The efficiency scores are generated from the structural KK model (Column 1 of Table 3); generating the efficiency scores from the extended model with policy variables leads to instability of scores due to variation in the number of observations.
} 
company, is based on software developed in Estonia. Online communications is not confined to social purposes. Estonia enjoys an efficient 'e government' system, which brings its citizens and state together through 'mouse clicks' instead of queues outside offices.

Along with the Czech Republic, Hungary attracts high quality foreign investment involving technical skills. Investment restrictions have also been lifted. Indeed, foreign ownership of banking operations preceded the privatisation process that began in earnest after the fall of the iron curtain. In effect, Hungary's move towards a market economy began far earlier than its communist neighbours.

At the other end of the scale, Lithuania, Slovakia and Slovenia fare worst, scoring close to one third of maximum values when averaged across the western countries. Even lower scores are obtained between country pairs; FDI performance is especially poor between Lithuania and Austria, between Slovakia and Italy and between Slovenia and Finland.

Averaging across the ten new EU member countries, the efficiency scores suggest Denmark, Germany and the Netherlands are the strongest FDI performers in the region. Of the western countries, Italy most frequently attains low scores with its eastern counterparts; its more inwardly nature indicates highest potential for bilateral FDI growth.

On the whole, the divergent efficiency scores suggest that countries which are closer to achieving FDI potential tend to be associated with the ability to attract high quality FDI. In other words, the composition of FDI matters for FDI performance. Countries with poorer FDI performance stand to gain the most by improving their institutional environment: easing investment restrictions in line with trade restrictions would considerably improve their prospects for achieving potential FDI. Maintaining relatively low wage and taxation rates coupled with the upkeep of a good infrastructural network is also crucial to attracting more FDI. 


\section{Conclusions}

In summary, asserting the exact nature of FDI to the eastern European countries is difficult, not least because the data do not distinguish between the differing types of FDI. Estimating a hybrid model that combines both types of firm motives serves to overcome this problem. In integrating the horizontal motive of MNEs aligned with the proximity advantages of local production and the avoidance of trade costs and the vertical motive of MNEs linked to dissimilar endowments of skilled labour, the KK model is estimated for a panel of FDI stocks from 10 western European countries to 10 new EU member countries over the transition period of 1996 to 2007.

The KK model results suggest a coexistence of HFDI and VFDI patterns. Similar country characteristics favour HFDI, taking place mainly between the high income countries (the GDP for both countries); between countries of sufficient size similarity (the squared difference of GDP); between countries relatively abundant in factor endowments (the difference of skilled labour); and the combined effect of size and factor similarities (the interaction term between the product of the differences in economic size and skilled labour endowments). Trade costs in the host country are also relevant to HFDI as it seeks to avoid transport costs and trade barriers by producing goods locally. In contrast, country characteristics that have a deterring effect on VFDI include the combined effect of trade costs and factor similarities (the interaction term between the host country trade costs and the square of skilled labour differences), high transport costs (the geographic distance) and costs involved in the reexport of goods back to the home country (trade costs in the source country). Investment restrictions also play a role in deterring both types of FDI. A comparison of the pre EU and the post EU subsamples indicate a reorientation towards the horizontal motive of FDI over time, suggesting that larger market size and the economics of large scale production now dominate trade barriers as a motivation for FDI. 
Using a stochastic frontier approach to estimating the KK model, the efficiency of FDI performance is identified relative to maximum potential levels. Overall, the FDI efficiency scores suggest a mixed degree of FDI integration with average FDI performance ranging from one third (Slovakia) to nearly two thirds (Hungary) of frontier estimates. Hungary's lead position is not surprising given its early liberalisation process and quest for high quality investment. Next in line is Estonia, its disdain for investment restrictions contributes to relatively high efficiency scores. At the other end of the spectrum, Lithuania, Slovakia and Slovenia stand to gain the most from further liberalisation according to the FDI efficiency scores. From the investor country perspective, high efficiency scores suggest least manoeuvre for better FDI performance emanates from France, Germany and the Netherlands in contrast to Italy, which has the greatest scope for more efficient FDI.

Improving bilateral FDI performance is important as the eastern European countries continue on their paths of liberalisation and catch up with their western counterparts. In the short term, improving their institutional environment by easing investment restrictions in line with trade restrictions would enhance their prospects for achieving potential FDI. The role of low wage and taxation rates in addition to a good infrastructural network also remains important in attracting FDI. In the longer term, attracting top quality FDI might best be achieved by an outward shift of the FDI frontier involving policies that develop specialised human capital activities as a complement to an already well-educated and skilled workforce. 


\section{References}

Aigner, D., Lovell, C.A. Knox, Schmidt, P., 1977. Formulation and estimation of stochastic frontier production function models. Journal of Econometrics 6, 21-37.

Anderson, J.E., van Wincoop, E., 2003. Gravity with gravitas: a solution to the border puzzle. American Economic Review 93, 170-192.

Armstrong, S., 2011. Assessing the scale and potential of Chinese investment overseas: an econometric approach. China \& World Economy 19, 22-37.

Battese, G.E., Coelli, T.J., 1993. A stochastic frontier production function incorporating a model for technical inefficiency effects. Working Paper No. 69. University of New England, Armidale.

Battese, G.E., Coelli, T.J., 1995. A model for technical inefficiency effects in a stochastic frontier production function for panel data. Empirical Economics 20, 325-332.

Bellak, C., Leibrecht, M., Riedl, A., 2008. Labour costs and FDI flows into central and eastern European countries: a survey of the literature and empirical evidence. Structural Change and Economic Dynamics 19, 17-37.

Bellak, C., Leibrecht, M., Damijan, J. P., 2009. Infrastructure endowment and corporate income taxes as determinants of foreign direct investment in central and eastern European countries. The World Economy 32, 267-290.

Bevan, A.A., Estrin, S., 2004. The determinants of foreign direct investment into European transition economies. Journal of Comparative Economics 32, 775-787.

Blonigen, B.A., Davies, R.B., Head, K., 2003. Estimating the knowledge capital model of the multinational enterprise: comment. American Economic Review 93, 980-994. 
Brainard, S.L., 1993. A simple theory of multinational corporations and trade with a trade-off between proximity and concentration. Working Paper No. 4269. NBER, Cambridge.

Carr, D.L., Markusen, J.R., Maskus, K.E., 2001. Estimating the knowledge capital model of the multinational enterprise. American Economic Review 91, 693-708.

Carstensen, K., Toubal, F., 2004. Foreign direct investment in central and eastern European countries: a dynamic panel analysis. Journal of Comparative Economics 32, 3-22.

Centre d'etudes prospectives et d'informations internationales, 2011. Available at http://www.cepii.fr/anglaisgraph/bdd/distances.htm. CEPII, Paris.

Clausing, K.A., Dorobantu, C.L., 2005. Re-entering Europe: does European Union candidacy boost foreign direct investment?. Economics of Transition 13, 77-103.

Davies, R.B., 2008. Hunting high and low for vertical FDI. Review of International Economics $16,250-267$.

Demekas, D.G., Balász, H., Ribakova, E., Wu, Y., 2007. Foreign direct investment in European transition economies - the role of policies. Journal of Comparative Economics 35, 369-386.

Egger, P., Pfaffermayr, M., 2004. Foreign direct investment and European integration in the 1990s. The World Economy 27, 99-110.

European Bank for Reconstruction and Development, 2011. Available at http://www.ebrd.com/pages/research/economics/data/macro.shtml. EBRD, London.

Fried, H.O., Lovell, C.A.K, Schmidt, S.S., 2008. Efficiency and productivity. In: Fried, H.O., Lovell, C.A.K, Schmidt, S.S. (Eds.), The measurement of productive efficiency and productivity growth, Oxford University Press, New York, pp. 3-91.

Globerman, S., Shapiro, D. M., 2002. Global foreign direct investment flows: The role of governance infrastructure. World Development 30, 1899-1919. 
Helpman, E., 1984. A simple theory of international trade with multinational corporations. Journal of Political Economy 92, 451-471.

Helpman, E., 1987. Imperfect competition and international trade: evidence from fourteen industrial Countries. Journal of the Japanese and International Economies 1, 62-81.

Helpman, E., Krugman, P.R., 1985. Market structure and foreign trade: increasing returns, imperfect competition, and the international economy. MIT Press, Cambridge, MA.

International Country Risk Guide, 2010. Available at http://www.prsgroup.com/icrg.aspx. ICRG, New York.

International Labour Organisation, 2011. Key Indicators of the Labour Market (KILM). ESDS International, Univ. of Manchester.

International Monetary Fund, 2011. International Financial Statistics (IFS). ESDS International, Univ. of Manchester.

Kristjánsdóttir, H., 2010. Foreign direct investment: the knowledge capital model and a small country case. Scottish Journal of Political Economy 57, 591-614.

Lipsey, R. E., 2000. Interpreting developed countries' foreign direct investment. Working Paper No. 7810. NBER, Cambridge.

Mariel, P., Orbe, S., Rodríguez, C., 2009. The knowledge capital model of FDI: a time varying coefficients approach. Scottish Journal of Political Economy 56, 196-212.

Markusen, J.R., 1984. Multinationals, multi-plant economies, and the gains from trade. Journal of International Economics 16, 205-226.

Markusen, J.R., 1997. Trade versus investment liberalisation. Working Paper No. 6231. NBER, Cambridge. 
Markusen, J.R., Maskus, K.E., 2001. Multinational firms: reconciling theory and evidence. In: Blomstrom, M. Goldberg, L.S. (Eds.), Topics in empirical international economics: a Festschrift in Honor of Robert E. Lipsey. Univ. of Chicago Press, Chicago, pp. 71-95.

Markusen, J.R, Maskus, K.E., 2002. Discriminating among alternative theories of the multinational enterprise. Review of International Economics 10, 694-707.

Markusen, J.R., Venables, A.J., Eby Konan, D., Zhang, K. H., 1996. A unified treatment of horizontal direct investment, vertical direct investment, and the pattern of trade in goods and services. Working Paper No. 5696. NBER, Cambridge.

Meeusen, W., van den Broeck, J., 1977. Efficiency estimation from Cobb-Douglas production functions with composed error. International Economic Review 18, 435-444.

Organisation for Economic Co-operation and Development, 2010. International Direct Investment Statistics (IDIS). ESDS International, Univ. of Manchester.

Resmini, L., 2000. The determinants of foreign direct investment in the CEECs: New evidence from sectoral patterns, Economics of Transition 8, 665-689.

Rodríguez, C., Gómez, C., Ferreiro, J., 2009. A proposal to improve UNCTAD’s inward FDI potential index. Transnational Corporations 18, 85-113.

Rojec, M., Damijan, J.P., 2008. Relocation via foreign direct investment from old to new EU member states: scale and structural dimension of the process. Structural Change and Economic Dynamics 19, 53-65.

Smarzynska Javorcik, B., 2004. Does foreign direct investment increase the productivity of domestic firms? In search of spillovers through backward linkages. American Economic Review 94, 605-627. 
The Heritage Foundation, 2012. Available at http://www.heritage.org. The Heritage Foundation, Washington.

United Nations Conference on Trade and Development (UNCTAD), 2002. World Investment Report (WIR). Transnational Corporations and Export Competitiveness, United Nations, New York and Geneva.

United Nations Conference on Trade and Development (UNCTAD), 2012. Available at http://www.unctadstat.unctad.org. United Nations, New York and Geneva.

World Bank, 2011. World Development Indicators (WDI). ESDS International, Univ. of Manchester.

Yeaple, S.R., 2003. The role of skill endowments in the structure of U.S. outward foreign direct investment. The Review of Economics and Statistics 85, 726-734. 
Table 1 Summary Statistics

\begin{tabular}{|c|c|c|c|c|c|}
\hline Variable & Mean & $\begin{array}{l}\text { Standard } \\
\text { deviation }\end{array}$ & Minimum & Maximum & No. of obs \\
\hline \multicolumn{6}{|l|}{ Location determinants } \\
\hline FDI Stocks & 5.48 & 2.07 & -2.30 & 9.88 & 942 \\
\hline Source country GDP & 26.81 & 1.02 & 25.33 & 28.36 & 1200 \\
\hline Host country GDP & 24.00 & 0.97 & 22.19 & 26.14 & 1200 \\
\hline GDP difference squared & 9.87 & 8.17 & $0.63 \times 10^{-4}$ & 35.91 & 1200 \\
\hline Distance & 6.92 & 0.61 & 4.09 & 7.66 & 1200 \\
\hline Skills difference & 0.16 & 0.44 & -0.86 & 1.45 & 1200 \\
\hline $\begin{array}{l}\text { GDP difference } \\
\times \text { Skills difference }\end{array}$ & 0.34 & 1.30 & -2.87 & 5.71 & 1200 \\
\hline $\begin{array}{l}\text { Host country trade costs } \\
\quad \times \text { Skills difference squared }\end{array}$ & 5.83 & 8.21 & $0.99 \times 10^{-5}$ & 54.92 & 1200 \\
\hline \multicolumn{6}{|l|}{ Inefficiency determinants } \\
\hline Source country trade costs & 20.19 & 3.75 & 10.80 & 36.40 & 1200 \\
\hline Host country trade costs & 26.04 & 9.54 & 13.40 & 53.20 & 1200 \\
\hline Host country investment costs & 33.75 & 12.66 & 10.00 & 70.00 & 1200 \\
\hline Host country labour costs & 105.16 & 14.31 & 74.8 & 163.00 & 1100 \\
\hline Host country economic stability & 35.21 & 4.11 & 19.00 & 43.00 & 1120 \\
\hline Host country political stability & 76.08 & 4.86 & 60.00 & 87.00 & 1120 \\
\hline Host country taxation & 22.33 & 5.90 & 10.00 & 40.00 & 700 \\
\hline $\begin{array}{l}\text { Host country gross capital } \\
\text { formation-to-GDP ratio }\end{array}$ & 26.41 & 5.99 & 0.30 & 40.39 & 1200 \\
\hline Host country infrastructure & 2.87 & 0.53 & 1.00 & 3.67 & 1080 \\
\hline
\end{tabular}


Table 2 Correlation Matrix

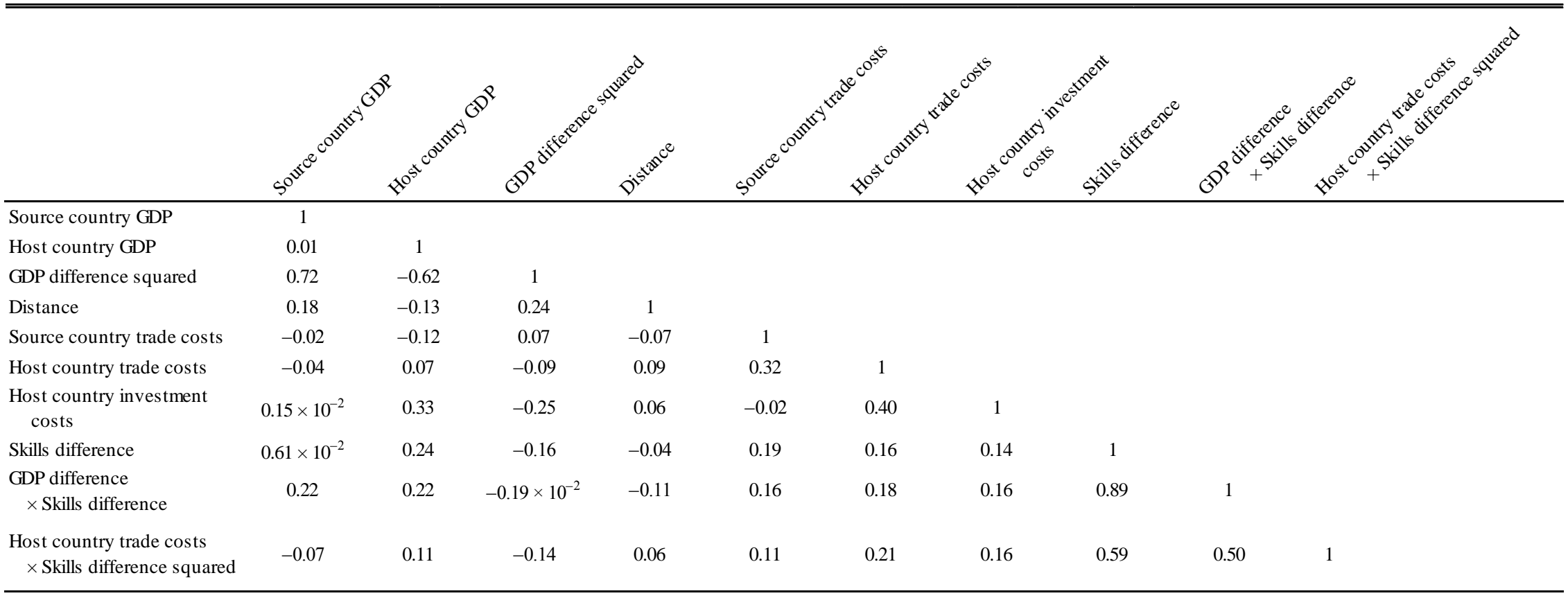


Table 3 A Stochastic Frontier Specification of FDI Determinants ${ }^{\mathrm{a}, \mathrm{b}, \mathrm{c}}$

\begin{tabular}{|c|c|c|c|c|}
\hline Regressors & Full sample $^{\mathrm{d}}$ & Pre EU ${ }^{\mathrm{d}}$ & Post EU ${ }^{\mathrm{d}}$ & Expected sign \\
\hline \multicolumn{5}{|l|}{ Location determinants } \\
\hline Source country GDP & $\begin{array}{l}1.24 * * * \\
(0.10)\end{array}$ & $\begin{array}{l}1.29 * * * \\
(0.12)\end{array}$ & $\begin{array}{c}0.88 * * * \\
(0.16)\end{array}$ & $(+)$ \\
\hline Host country GDP & $\begin{array}{c}0.48 * * * \\
(0.09)\end{array}$ & $\begin{array}{l}0.34 * * * \\
(0.11)\end{array}$ & $\begin{array}{l}0.95 * * * \\
(0.17)\end{array}$ & $(+)$ \\
\hline GDP difference squared & $\begin{array}{l}-0.15 * * * \\
(0.01)\end{array}$ & $\begin{array}{c}-0.17 * * * \\
(0.02)\end{array}$ & $\begin{array}{c}-0.09 * * * \\
(0.03)\end{array}$ & $(-)$ \\
\hline Distance & $\begin{array}{l}-1.19 * * * \\
\quad(0.07)\end{array}$ & $\begin{array}{l}-1.18 * * * \\
\quad(0.08)\end{array}$ & $\begin{array}{l}-1.10 * * * \\
(0.11)\end{array}$ & $(-)$ \\
\hline Skills difference & $\begin{array}{c}-1.47 * * * \\
(0.20)\end{array}$ & $\begin{array}{l}-1.22 * * * \\
(0.25)\end{array}$ & $\begin{array}{l}-2.18 * * * \\
(0.37)\end{array}$ & $(+)$ \\
\hline $\begin{array}{l}\text { GDP difference } \\
\quad \times \text { Skills difference }\end{array}$ & $\begin{array}{c}0.69 * * * \\
(0.07)\end{array}$ & $\begin{array}{c}0.71 * * * \\
(0.08)\end{array}$ & $\begin{array}{c}0.89 * * * \\
(0.13)\end{array}$ & $(-)$ \\
\hline $\begin{array}{l}\text { Host country trade costs } \\
\times \text { Skills difference squared }\end{array}$ & $\begin{array}{l}-0.05 * * * \\
(0.01)\end{array}$ & $\begin{array}{l}-0.05 * * * \\
(0.01)\end{array}$ & $\begin{array}{c}-0.08 * * * \\
(0.02)\end{array}$ & $(-)$ \\
\hline Intercept & $\begin{array}{c}-28.48 * * * \\
(1.42)\end{array}$ & $\begin{array}{c}-26.34 * * * \\
(1.86)\end{array}$ & $\begin{array}{c}-30.81 * * * \\
(2.52)\end{array}$ & \\
\hline \multicolumn{5}{|l|}{ Inefficiency determinants } \\
\hline Source country trade costs & $\begin{array}{c}0.13 * * * \\
(0.03)\end{array}$ & $\begin{array}{c}0.13 * * \\
(0.04)\end{array}$ & $\begin{array}{l}0.06 \\
(0.04)\end{array}$ & $(+)$ \\
\hline Host country trade costs & $\begin{array}{l}0.22 \times 10^{-2} \\
\quad(0.01)\end{array}$ & $\begin{array}{l}-0.01 \\
(0.70)\end{array}$ & $\begin{array}{c}-0.03 * \\
(0.02)\end{array}$ & $(-)$ \\
\hline Host country investment costs & $\begin{array}{l}0.01 * \\
(0.01)\end{array}$ & $\begin{array}{c}0.01 \\
(0.01)\end{array}$ & $\begin{array}{c}0.03 * * * \\
(0.01)\end{array}$ & $(+)$ \\
\hline No. of obs & 942 & 628 & 314 & \\
\hline$\gamma^{\mathrm{e}}$ & $\begin{array}{c}0.78 * * \\
(0.05)\end{array}$ & $\begin{array}{c}0.83 * * * \\
(0.05)\end{array}$ & $\begin{array}{c}0.68 \\
(0.17)\end{array}$ & \\
\hline \multicolumn{5}{|c|}{$\begin{array}{l}\text { d The full sample period refers to } 1996 \text { to } 2007 \text {. The pre EU accession subsample refers to the years } 1996 \text { to } 2003 \text { for } \\
\text { eight eastern European countries and } 1996 \text { to } 2006 \text { for the two newer member countries. The post EU accession } \\
\text { subsample refers to the years } 2004 \text { to } 2007 \text { and } 2007 \text { for the two groups of countries respectively. } \\
\text { e } \gamma=\sigma_{u}^{2} / \sigma_{u}^{2} \text { : the ratio of the variance of the inefficiency component to the variance of the random error. } \\
* * * \text { is significant at the } 1 \% \text { level; } * * \text { is significant at the } 5 \% \text { level; * is significant at the } 10 \% \text { level. }\end{array}$} \\
\hline
\end{tabular}


Table 4 Robustness Checks ${ }^{\mathrm{a}, \mathrm{b}}$

\begin{tabular}{|c|c|c|c|c|c|c|c|c|c|c|}
\hline Regressors & (1) & (2) & (3) & (4) & $(5)$ & (6) & (7) & (8) & (9) & $\begin{array}{l}\text { Expected } \\
\text { sign }\end{array}$ \\
\hline Source country GDP & $\begin{array}{l}1.54 * * * \\
(0.10)\end{array}$ & $\begin{array}{l}1.27 * * * \\
(0.09)\end{array}$ & $\begin{array}{l}1.37 * * * \\
(0.10)\end{array}$ & $\begin{array}{c}1.25 * * * \\
(0.10)\end{array}$ & $\begin{array}{l}1.31 * * \\
(0.11)\end{array}$ & $\begin{array}{c}1.16^{* * *} \\
(0.10)\end{array}$ & $\begin{array}{c}1.11 * * * \\
(0.10)\end{array}$ & $\begin{array}{l}1.11^{* * * *} \\
(0.08)\end{array}$ & $\begin{array}{l}1.68 * * * \\
(0.22)\end{array}$ & $(+)$ \\
\hline Host country GDP & $\begin{array}{c}0.38 * * * \\
(0.09)\end{array}$ & $\begin{array}{c}0.50 * * * \\
(0.08)\end{array}$ & $\begin{array}{c}0.50 * * * \\
(0.09)\end{array}$ & $\begin{array}{c}0.48 * * * \\
(0.09)\end{array}$ & $\begin{array}{c}0.57 * * * \\
(0.11)\end{array}$ & $\begin{array}{c}0.54 * * * \\
(0.09)\end{array}$ & $\begin{array}{l}2.71 * * * \\
(0.31)\end{array}$ & $\begin{array}{l}2.71 * * * \\
(0.30)\end{array}$ & $\begin{array}{l}0.58 * * * \\
(0.22)\end{array}$ & $(+)$ \\
\hline GDP difference squared & $\begin{array}{c}-0.17 * * * \\
(0.02)\end{array}$ & $\begin{array}{l}-0.14 * * * \\
\quad(0.01)\end{array}$ & $\begin{array}{l}-0.15 * * * \\
\quad(0.02)\end{array}$ & $\begin{array}{l}-0.15 * * * \\
\quad(0.01)\end{array}$ & $\begin{array}{l}-0.14 * * * \\
\quad(0.02)\end{array}$ & $\begin{array}{l}-0.14 * * * \\
(0.02)\end{array}$ & $\begin{array}{l}-0.13 * * * \\
(0.02)\end{array}$ & $\begin{array}{l}-0.13 * * * \\
(0.01)\end{array}$ & $\begin{array}{l}-0.17 * * * \\
(0.04)\end{array}$ & $(-)$ \\
\hline Distance & $\begin{array}{c}-1.41 * * * \\
(0.07)\end{array}$ & $\begin{array}{c}-1.26 * * * \\
(0.06)\end{array}$ & $\begin{array}{c}-1.29 * * * \\
(0.06)\end{array}$ & $\begin{array}{c}-1.19 * * * \\
(0.07)\end{array}$ & $\begin{array}{c}-1.38 * * * \\
(0.07)\end{array}$ & $\begin{array}{c}-1.13 * * * \\
(0.07)\end{array}$ & $\begin{array}{c}-1.30 * * * \\
\quad(0.07)\end{array}$ & $\begin{array}{c}-1.30 * * * \\
(0.06)\end{array}$ & $\begin{array}{l}-1.53 * * * \\
(0.16)\end{array}$ & $(-)$ \\
\hline Skills difference & $\begin{array}{c}-0.32 * * * \\
(0.10)\end{array}$ & $\begin{array}{c}-1.96 * * * \\
(0.19)\end{array}$ & - & $\begin{array}{l}-1.42 * * * \\
\quad(0.20)\end{array}$ & - & $\begin{array}{l}-1.51 * * * \\
\quad(0.21)\end{array}$ & $\begin{array}{l}-1.55 * * * \\
\quad(0.21)\end{array}$ & $\begin{array}{l}-1.55 * * * \\
(0.17)\end{array}$ & $\begin{array}{l}-0.87 * * * \\
(0.30)\end{array}$ & $(+)$ \\
\hline $\begin{array}{l}\text { GDP difference } \\
\times \text { Skills difference }\end{array}$ & - & $\begin{array}{c}0.74 * * * \\
(0.06)\end{array}$ & $\begin{array}{c}0.29 * * * \\
(0.04)\end{array}$ & $\begin{array}{c}0.68 * * * \\
(0.07)\end{array}$ & - & $\begin{array}{c}0.73 * * * \\
(0.07)\end{array}$ & $\begin{array}{c}0.81 * * * \\
(0.07)\end{array}$ & $\begin{array}{c}0.81^{* * *} \\
(0.07)\end{array}$ & $\begin{array}{r}0.21 * * \\
(0.09)\end{array}$ & $(-)$ \\
\hline $\begin{array}{l}\text { Host country trade costs } \\
\quad \times \text { Skills difference squared }\end{array}$ & - & $\begin{array}{l}-0.44 \times 10^{-2} \\
\quad(0.00)\end{array}$ & $\begin{array}{l}-0.43 \times 10^{-2} \\
\quad(0.01)\end{array}$ & $\begin{array}{c}-0.37 \times 10^{-2} \\
(0.02)\end{array}$ & - & $\begin{array}{l}-0.05 * * * \\
(0.01)\end{array}$ & $\begin{array}{c}-0.04 * * * \\
(0.01)\end{array}$ & $\begin{array}{c}-0.04 * * * \\
(0.01)\end{array}$ & $\begin{array}{c}-0.01^{* *} \\
(0.01)\end{array}$ & $(-)$ \\
\hline $\begin{array}{l}\text { Skills difference in absolute } \\
\text { values }\end{array}$ & - & - & $\begin{array}{l}-1.77 * * * \\
(0.31)\end{array}$ & - & - & - & - & - & - & $(+)$ \\
\hline Skills difference squared & - & - & - & $\begin{array}{l}-1.22 * * \\
(0.51)\end{array}$ & - & - & - & - & - & $(+)$ \\
\hline Skills2 difference & - & - & - & - & $\begin{array}{c}0.76 \\
(0.83)\end{array}$ & - & - & - & - & $(+)$ \\
\hline $\begin{array}{l}\text { GDP difference } \\
\quad \times \text { Skills2 difference }\end{array}$ & - & - & - & - & $\begin{array}{c}0.68 * * * \\
(0.25)\end{array}$ & - & - & - & - & $(-)$ \\
\hline $\begin{array}{l}\text { Host country trade costs } \\
\quad \times \text { Skills } 2 \text { difference squared }\end{array}$ & - & - & - & - & $\begin{array}{c}-0.34 * * * \\
(0.06)\end{array}$ & - & - & - & - & $(-)$ \\
\hline Fixed effects & - & - & - & - & - & - & Yes & Yes & - & \\
\hline Intercept & $\begin{array}{c}-32.31 * * * \\
(1.47)\end{array}$ & $\begin{array}{c}-29.60 * * * \\
(1.47)\end{array}$ & $\begin{array}{c}-30.83 * * * \\
(1.45)\end{array}$ & $\begin{array}{c}-28.61 * * * \\
(1.41)\end{array}$ & $\begin{array}{c}-31.27 * * * \\
(1.51)\end{array}$ & $\begin{array}{c}-28.28 * * * \\
(1.48)\end{array}$ & $\begin{array}{c}-78.00 * * * \\
(6.94)\end{array}$ & $\begin{array}{c}-78.00 * * * \\
(6.85)\end{array}$ & $\begin{array}{c}-40.50 * * \\
(3.35)\end{array}$ & \\
\hline \multicolumn{11}{|l|}{ Inefficiency determinants } \\
\hline Source country trade costs & $\begin{array}{c}0.13 * * * \\
(0.03)\end{array}$ & - & $\begin{array}{c}0.11 * * * \\
(0.02)\end{array}$ & $\begin{array}{c}0.12 * * * \\
(0.03)\end{array}$ & $\begin{array}{c}0.13 * * * \\
(0.03)\end{array}$ & $\begin{array}{l}0.22 * \\
(0.12)\end{array}$ & $\begin{array}{l}-0.02 \\
(0.01)\end{array}$ & $\begin{array}{l}-0.02 \\
(0.01)\end{array}$ & $\begin{array}{c}-0.07 * * * \\
(0.01)\end{array}$ & $(+)$ \\
\hline Host country trade costs & $\begin{array}{l}-0.35 \times 10^{-2} \\
(0.01)\end{array}$ & - & $\begin{array}{l}0.48 \times 10^{-2} \\
(0.01)\end{array}$ & $\begin{array}{c}0.01 \\
(0.01)\end{array}$ & $\begin{array}{l}-0.02^{*} \\
(0.01)\end{array}$ & $\begin{array}{l}-0.03 \\
(0.03)\end{array}$ & $\begin{array}{l}0.68 \times 10^{-2} \\
(0.01)\end{array}$ & $\begin{array}{l}0.68 \times 10^{-2} \\
(0.01)\end{array}$ & $\begin{array}{c}-0.46 \times 10^{-2} \\
(0.00)\end{array}$ & $(-)$ \\
\hline Host country investment costs & $\begin{array}{l}0.01^{*} \\
(0.01)\end{array}$ & - & $\begin{array}{l}0.01^{*} \\
(0.01)\end{array}$ & $\begin{array}{l}0.01 * \\
(0.01)\end{array}$ & $\begin{array}{l}0.01^{*} \\
(0.01)\end{array}$ & $\begin{array}{c}0.03 \\
(0.02)\end{array}$ & $\begin{array}{l}0.01^{*} \\
(0.00)\end{array}$ & $\begin{array}{l}0.01^{*} \\
(0.00)\end{array}$ & $\begin{array}{c}0.01 * * * \\
(0.00)\end{array}$ & $(+)$ \\
\hline $\begin{array}{l}\text { Source country trade intensity } \\
\text { costs }\end{array}$ & - & $\begin{array}{c}0.01 * * * \\
(0.00)\end{array}$ & - & - & - & - & - & - & - & $(+)$ \\
\hline Host country trade intensity costs & - & $\begin{array}{c}-0.01 * * * \\
(0.00)\end{array}$ & - & - & - & - & - & - & - & $(-)$ \\
\hline Host country FDI intensity costs & - & $\begin{array}{l}5.08 * * * \\
(0.61)\end{array}$ & - & - & - & - & - & - & - & $(+)$ \\
\hline No. of obs & 942 & 934 & 942 & 942 & 942 & 790 & 942 & 942 & 895 & \\
\hline
\end{tabular}




$\begin{array}{lcccccc}\gamma^{\mathrm{c}} & 0.80 * * & 0.54 & 0.81 * * * & 0.78^{* * *} & 0.75^{* * *} & 0.88^{* * *} \\ & (0.05) & (0.09) & (0.05) & (0.05) & (0.06) & (0.06)\end{array}$

${ }^{a}$ Robustness checks on the KK model proxy variables are shown in columns (1-6). In column (1), the two interaction terms are excluded due to correlation with the skills

difference variable. In column (2), the restriction indexes determining inefficiency are redefined in terms of trade and investment intensities (Blonigen et al., 2003). In column (3),

the skills difference variable is respecified in absolute values (Blonigen et al. 2003). In column (4), the square of the skills difference variable is appended to the KK model

specification (Davies 2008). In column (5), the KK model is reestimated with the difference between secondary school enrolment rates and its associated interactions

(Kristjánsdóttir 2010). Finally, in column (6), the original KK model is reestimated for the subsample period 1999 to 2007 corresponding to when a full set of information is

available for tertiary enrolment rates. Robustness checks on the SFA maximum likelihood estimates are shown in columns (7-9). In column (7), country dummies are included to

allow for heterogeneity among the group of 10 eastern European countries. In column (8), the standard errors in column (7) are adjusted for heteroscedasticity. Finally, to

alleviate endogeneity bias, the KK model is reestimated in column (9) using the two stage least squares (2SLS) approach with one period lagged values used to instrument for the

GDP related variables and the investment cost index.

${ }^{\mathrm{b}}$ Standard errors are reported in parentheses.

${ }^{c} \gamma=\sigma_{u}^{2} / \sigma^{2}$ : the ratio of the variance of the inefficiency component to the variance of the random error.

$* * *$ is significant at the $1 \%$ level; ** is significant at the $5 \%$ level; * is significant at the $10 \%$ level. 
Table 5 Additional Inefficiency Determinants ${ }^{\mathrm{a}, \mathrm{b}}$

\begin{tabular}{|c|c|c|c|c|c|c|c|c|c|c|}
\hline Regressors & (1) & (2) & (3) & (4) & $(5)$ & (6) & (7) & (8) & $(9)$ & $\begin{array}{c}\text { Expected } \\
\text { sign } \\
\end{array}$ \\
\hline \multicolumn{11}{|l|}{ Location determinants } \\
\hline Source country GDP & $\begin{array}{c}1.08 * * * \\
(0.10)\end{array}$ & $\begin{array}{c}1.22 * * * \\
(0.10)\end{array}$ & $\begin{array}{c}1.22 * * * \\
(0.10)\end{array}$ & $\begin{array}{c}1.10 * * * \\
(0.11)\end{array}$ & $\begin{array}{c}1.20 * * * \\
(0.10)\end{array}$ & $\begin{array}{c}1.21 * * * \\
(0.09)\end{array}$ & $\begin{array}{c}1.04 * * * \\
(0.12)\end{array}$ & $\begin{array}{l}1.13 * * * \\
(0.09)\end{array}$ & $\begin{array}{c}1.27 * * * \\
(0.09)\end{array}$ & $(+)$ \\
\hline Host country GDP & $\begin{array}{c}0.64 * * * \\
(0.09)\end{array}$ & $\begin{array}{c}0.49 * * * \\
(0.09)\end{array}$ & $\begin{array}{c}0.49^{* * * *} \\
(0.09)\end{array}$ & $\begin{array}{c}0.72 * * * \\
(0.10)\end{array}$ & $\begin{array}{c}0.52 * * * \\
(0.09)\end{array}$ & $\begin{array}{c}0.33 * * * \\
(0.09)\end{array}$ & $\begin{array}{c}0.57 * * * \\
(0.12)\end{array}$ & $\begin{array}{c}0.57 * * * \\
(0.09)\end{array}$ & $\begin{array}{c}0.33 * * * \\
(0.10)\end{array}$ & $(+)$ \\
\hline GDP difference squared & $\begin{array}{c}-0.13 * * * \\
(0.02)\end{array}$ & $\begin{array}{c}-0.15 * * * \\
(0.02)\end{array}$ & $\begin{array}{c}-0.15 * * * \\
(0.02)\end{array}$ & $\begin{array}{c}-0.14 * * * \\
(0.02)\end{array}$ & $\begin{array}{c}-0.15 * * * \\
(0.02)\end{array}$ & $\begin{array}{c}-0.15 * * * \\
(0.01)\end{array}$ & $\begin{array}{c}-0.12 * * * \\
(0.02)\end{array}$ & $\begin{array}{c}-0.14 * * * \\
(0.01)\end{array}$ & $\begin{array}{c}-0.16^{* * *} \\
(0.02)\end{array}$ & $(-)$ \\
\hline Distance & $\begin{array}{l}-1.16^{* * * *} \\
(0.07)\end{array}$ & $\begin{array}{l}-1.17 * * * \\
(0.07)\end{array}$ & $\begin{array}{l}-1.19^{* * *} \\
(0.07)\end{array}$ & $\begin{array}{l}-1.20 * * * \\
(0.07)\end{array}$ & $\begin{array}{c}-1.15^{* * *} \\
(0.07)\end{array}$ & $\begin{array}{l}-1.21 * * * \\
(0.07)\end{array}$ & $\begin{array}{l}-1.15^{* * *} \\
\quad(0.08)\end{array}$ & $\begin{array}{l}-1.20 * * * \\
(0.06)\end{array}$ & $\begin{array}{l}-1.24 * * * \\
(0.07)\end{array}$ & $(-)$ \\
\hline Skills difference & $\begin{array}{l}-1.55^{* * *} \\
\quad(0.21)\end{array}$ & $\begin{array}{l}-1.46^{* * * *} \\
(0.20)\end{array}$ & $\begin{array}{l}-1.46^{* * *} \\
(0.20)\end{array}$ & $\begin{array}{l}-1.67 * * * \\
(0.23)\end{array}$ & $\begin{array}{c}-1.56^{* * * *} \\
(0.20)\end{array}$ & $\begin{array}{l}-1.78^{* * *} \\
(0.21)\end{array}$ & $\begin{array}{l}-1.90^{* * * *} \\
(0.24)\end{array}$ & $\begin{array}{l}-1.58 * * * \\
(0.20)\end{array}$ & $\begin{array}{l}-1.53 * * * \\
(0.20)\end{array}$ & $(+)$ \\
\hline $\begin{array}{l}\text { GDP difference } \\
\times \text { Skills difference }\end{array}$ & $\begin{array}{c}0.78 * * * \\
(0.07)\end{array}$ & $\begin{array}{c}0.70 * * * \\
(0.07)\end{array}$ & $\begin{array}{c}0.68 * * * \\
(0.07)\end{array}$ & $\begin{array}{c}0.81 * * * \\
(0.08)\end{array}$ & $\begin{array}{c}0.73 * * * \\
(0.07)\end{array}$ & $\begin{array}{c}0.87 * * * \\
(0.07)\end{array}$ & $\begin{array}{c}0.94 * * * \\
(0.09)\end{array}$ & $\begin{array}{c}0.77 * * * \\
(0.07)\end{array}$ & $\begin{array}{c}0.69 * * * \\
(0.07)\end{array}$ & $(-)$ \\
\hline $\begin{array}{l}\text { Host country trade costs } \\
\times \text { Skills difference squared }\end{array}$ & $\begin{array}{c}-0.05 * * * \\
(0.01)\end{array}$ & $\begin{array}{c}-0.05 * * * \\
(0.01)\end{array}$ & $\begin{array}{c}-0.05^{* * * *} \\
(0.01)\end{array}$ & $\begin{array}{c}-0.04 * * * \\
(0.01)\end{array}$ & $\begin{array}{c}-0.05 * * * \\
(0.01)\end{array}$ & $\begin{array}{c}-0.04 * * * \\
(0.01)\end{array}$ & $\begin{array}{c}-0.04 * * * \\
(0.01)\end{array}$ & $\begin{array}{c}-0.05 * * * \\
(0.01)\end{array}$ & $\begin{array}{c}-0.04 * * * \\
(0.01)\end{array}$ & $(-)$ \\
\hline Intercept & $\begin{array}{c}-28.79 * * * \\
(1.45)\end{array}$ & $\begin{array}{c}-28.37 * * * \\
(1.42)\end{array}$ & $\begin{array}{c}-28.30 * * * \\
(1.48)\end{array}$ & $\begin{array}{c}-28.80^{* * *} \\
(1.73)\end{array}$ & $\begin{array}{c}-28.57 * * * \\
(1.42)\end{array}$ & $\begin{array}{c}-22.54 * * * \\
(1.56)\end{array}$ & $\begin{array}{c}-24.41 * * * \\
(2.34)\end{array}$ & $\begin{array}{c}-27.79 * * * \\
(1.40)\end{array}$ & $\begin{array}{c}-25.33 * * * \\
(2.08)\end{array}$ & \\
\hline \multicolumn{11}{|l|}{ Inefficiency determinants } \\
\hline Source country trade costs & $\begin{array}{c}0.08 * * \\
(0.03)\end{array}$ & $\begin{array}{c}0.13 * * * \\
(0.03)\end{array}$ & $\begin{array}{c}0.14 * * * \\
(0.04)\end{array}$ & $\begin{array}{l}0.03 * \\
(0.01)\end{array}$ & $\begin{array}{c}0.12 * * * \\
(0.03)\end{array}$ & $\begin{array}{c}0.03 * * * \\
(0.01)\end{array}$ & $\begin{array}{c}0.01 \\
(0.02)\end{array}$ & $\begin{array}{c}0.01 \\
(0.02)\end{array}$ & $\begin{array}{c}0.12 \\
(0.02)\end{array}$ & $(+)$ \\
\hline Host country trade costs & $\begin{array}{c}-0.03^{* * *} \\
(0.02)\end{array}$ & $\begin{array}{l}0.14 \times 10^{-2} \\
(0.01)\end{array}$ & $\begin{array}{l}0.19 \times 10^{-2} \\
(0.01)\end{array}$ & $\begin{array}{c}-0.02 * * \\
(0.01)\end{array}$ & $\begin{array}{c}-0.15 \times 10^{-2} \\
(0.01)\end{array}$ & $\begin{array}{c}-0.19 \times 10^{-2} \\
(0.00)\end{array}$ & $\begin{array}{c}-0.91 \times 10^{-2} \\
(0.01)\end{array}$ & $\begin{array}{c}-0.02 * * \\
(0.01)\end{array}$ & $\begin{array}{c}0.02^{* *} \\
(0.01)\end{array}$ & $(-)$ \\
\hline Host country investment costs & $\begin{array}{c}0.02 * * \\
(0.01)\end{array}$ & $\begin{array}{c}0.01 \\
(0.01)\end{array}$ & $\begin{array}{c}0.01 \\
(0.01)\end{array}$ & $\begin{array}{c}0.01 * * * \\
(0.00)\end{array}$ & $\begin{array}{c}0.01 \\
(0.01)\end{array}$ & $\begin{array}{c}-0.53 \times 10^{-2} \\
(0.00)\end{array}$ & $\begin{array}{c}0.19 \times 10^{-2} \\
(0.01)\end{array}$ & $\begin{array}{l}0.02 * * \\
(0.01)\end{array}$ & $\begin{array}{c}-0.02 * * \\
(0.01)\end{array}$ & $(+)$ \\
\hline Host country labour costs & $\begin{array}{c}-0.05 * * * \\
(0.02)\end{array}$ & - & - & - & - & $(\infty)$, & $\begin{array}{c}-0.01 * * \\
(0.01)\end{array}$ & - & - & $(+)$ \\
\hline Host country economic stability & $(0.02)$ & $\begin{array}{l}-0.03 \\
(0.03)\end{array}$ & - & - & - & - & $\begin{array}{c}0.03 \\
(0.02)\end{array}$ & - & - & $(-)$ \\
\hline Host country political stability & - & - & $\begin{array}{c}-0.14 \times 10^{-2} \\
(0.02)\end{array}$ & - & - & - & $\begin{array}{c}0.44 \times 10^{-2} \\
(0.01)\end{array}$ & - & - & $(-)$ \\
\hline Host country taxation & - & - & $(0.02)$ & $\begin{array}{c}0.05 * * * \\
(0.01)\end{array}$ & - & - & $\begin{array}{r}0.02 * * \\
(0.01)\end{array}$ & - & - & $(+)$ \\
\hline $\begin{array}{l}\text { Host country gross capital } \\
\text { formation-to-GDP ratio }\end{array}$ & - & - & - & - & $\begin{array}{c}-0.04 * * * \\
(0.02)\end{array}$ & - & $\begin{array}{c}0.01 \\
(0.02)\end{array}$ & - & - & $(-)$ \\
\hline Host country infrastructure & - & - & - & - & - & $\begin{array}{c}-1.19 * * * \\
(0.09)\end{array}$ & $\begin{array}{c}-0.85^{* * *} * \\
(0.20)\end{array}$ & - & - & $(-)$ \\
\hline Time effects & - & - & - & - & - & - & - & Yes & - & \\
\hline Fixed effects & - & - & - & - & - & - & - & - & Yes & \\
\hline No. of obs & 866 & 919 & 919 & 629 & 942 & 831 & 506 & 942 & 942 & \\
\hline$\gamma^{\mathrm{c}}$ & $0.75 * * *$ & $0.78 * * *$ & $0.79 * * *$ & 1.00 & $0.78 * * *$ & $0.95^{* *}$ & $0.88 * * *$ & $0.68 * * *$ & $0.72 * * *$ & \\
\hline
\end{tabular}


${ }^{a}$ The additional FDI inefficiency determinants in the eastern European countries include an array of policy factors. In column (1), the cost of labour is measured as the real

manufacturing wage index. Columns (2) and (3) include international perception measures of economic and political instability respectively. Column (4) refers to taxation,

defined as the highest marginal tax rate applied to the taxable income of corporations. In column (5), domestic capital stocks is measured by gross capital formation as a share of

GDP. In column (6), physical infrastructure refers to the reform of telecommunications, railways, electric power, roads as well as water and waste water. Putting all the policy

variables together, the results for the full model are shown in column (7). In columns (8) and (9), the policy variables are replaced with time effects or host country fixed effects respectively.

${ }^{\mathrm{b}}$ Standard errors are reported in parentheses.

$\gamma=\sigma_{u}^{2} / \sigma_{u}^{2}$ : the ratio of the variance of the inefficiency component to the variance of the random error.

*** is significant at the $1 \%$ level; ** is significant at the $5 \%$ level; * is significant at the $10 \%$ level. 
Table 6 Efficiency Score Estimates from the Stochastic Frontier Specification of the Knowledge Capital Model, 1996-2007

\begin{tabular}{ccccccccccccc}
\hline \hline & AUT & DNK & FIN & FRA & DEU & ITA & NLD & NOR & CHE & UK & Average \\
\hline BGR & 0.50 & 0.40 & - & 0.36 & 0.48 & 0.52 & 0.52 & 0.14 & 0.53 & 0.36 & 0.42 \\
CZE & 0.49 & 0.53 & 0.32 & 0.41 & 0.45 & 0.16 & 0.60 & 0.42 & 0.48 & 0.31 & 0.42 \\
EST & 0.40 & 0.66 & 0.43 & 0.51 & 0.45 & 0.49 & 0.50 & 0.59 & - & 0.57 & 0.51 \\
HUN & 0.46 & 0.41 & 0.60 & 0.54 & 0.70 & 0.22 & 0.70 & 0.51 & 0.45 & 0.54 & 0.51 \\
LVA & 0.33 & 0.66 & 0.44 & 0.26 & 0.56 & 0.33 & 0.30 & 0.49 & - & 0.48 & 0.43 \\
LTU & 0.12 & 0.75 & 0.49 & 0.45 & 0.39 & 0.13 & 0.18 & 0.44 & - & 0.26 & 0.36 \\
POL & 0.30 & 0.50 & 0.41 & 0.45 & 0.30 & 0.35 & 0.54 & 0.26 & 0.40 & 0.26 & 0.38 \\
ROM & 0.54 & 0.17 & 0.31 & 0.54 & 0.46 & 0.34 & 0.50 & 0.42 & 0.49 & 0.28 & 0.41 \\
SVK & 0.16 & 0.34 & 0.31 & 0.33 & 0.51 & 0.14 & 0.43 & 0.50 & 0.24 & 0.17 & 0.31 \\
SVN & 0.48 & 0.33 & 0.13 & 0.53 & 0.36 & 0.21 & 0.28 & - & - & 0.22 & 0.32 \\
Average & 0.38 & 0.48 & 0.38 & 0.44 & 0.47 & 0.29 & 0.46 & 0.42 & 0.43 & 0.35 & - \\
\hline
\end{tabular}

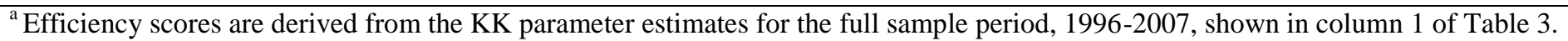


Figure 1 FDI Outward Stocks from the EU-8 and the EFTA-2 Countries to the NMS

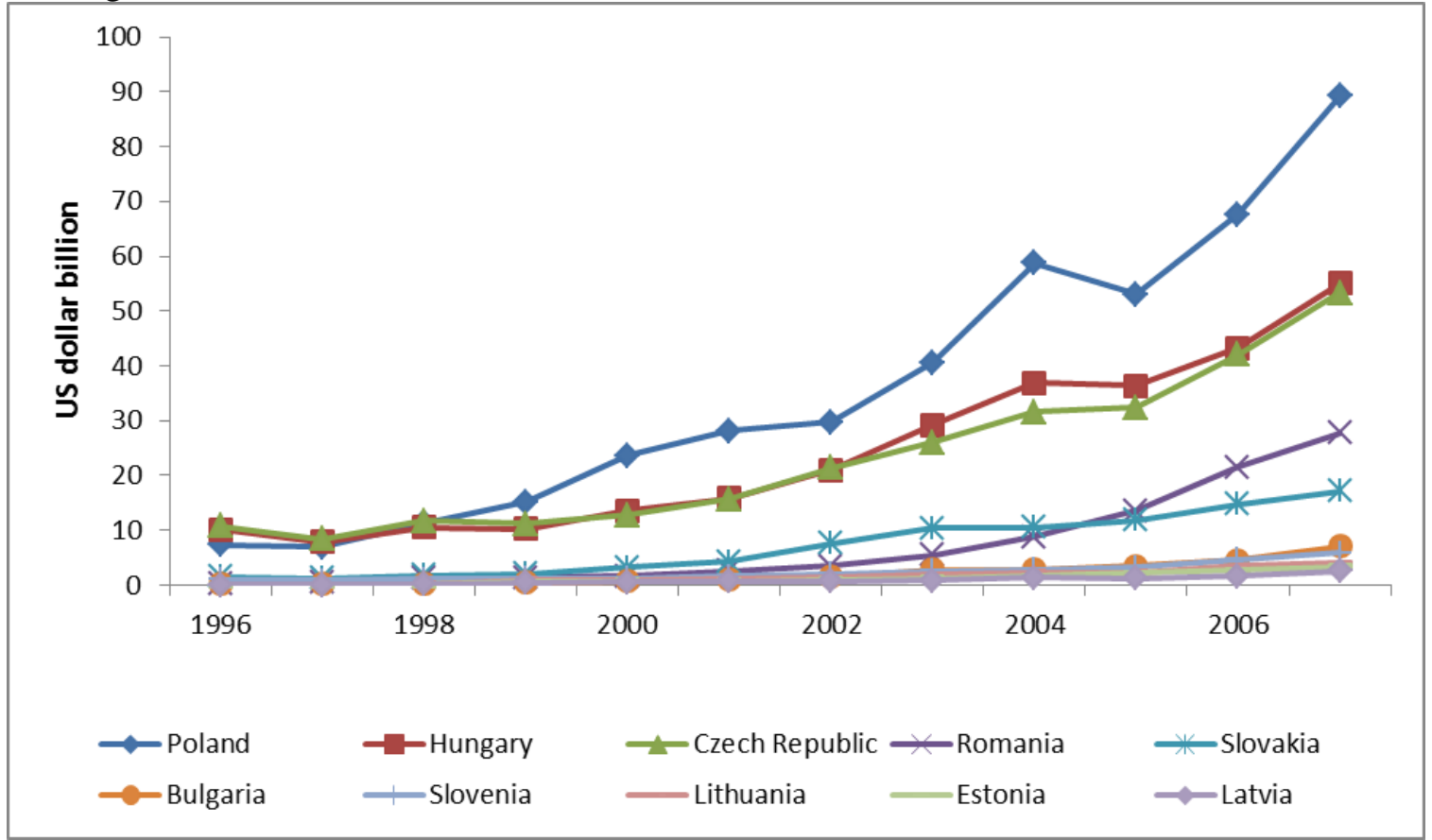

Source: International Direct Investment Statistics, OECD. 